Artur ZAWADA $^{1}$

Opiekun naukowy: Jacek RYSIŃSKI ${ }^{2}$

DOI: https://doi.org/10.53052/9788366249837.38

\title{
ANALIZA KINEMATYKI RUCHU RAMIENIA ROBOTA HUMANOIDALNEGO
}

\begin{abstract}
Streszczenie: Projekt ramienia robota humanoidalnego jest trudnym zadaniem pod względem konstrukcyjnym jak i programistycznym, ponieważ najwięcej komplikacji sprawia zapewnienie stabilnego ruchu kończyny. Przeglądając literaturę można znaleźć wiele informacji związanych z budową dłoni, jednakże bardzo mało jest na temat ruchu całej ręki. W niniejszym artykule podjęto próbę określenia sposobu podejścia do tego zagadnienia analizując kinematykę jednej z kończyn. Dla wybranego przykładu wyznaczone zostały równania kinematyki odwrotnej umożliwiające precyzyjne zadawanie pozycji w układzie kartezjańskim.
\end{abstract}

Słowa kluczowe: ramie robota, równania kinematyki odwrotnej, analiza chodu

\section{KINEMATIC MOTION ANALYSIS OF THE ROBOT ARM}

\begin{abstract}
The design of the humanoid robot arm is a difficult task both in terms of design and programming, because the most complications are ensuring the stable movement of the limb. While browsing the literature, we can find a lot of information related to the structure of the hand, however, there is very little about the movement of the whole hand. This article attempts to define the approach to this issue by analyzing the kinematics of one of the limbs. For the selected example, the inverse kinematics equations were determined, enabling precise setting of the position in the Cartesian system
\end{abstract}

Keywords: Humanoid arms, inverse kinematic, Walkthrough

\section{Wstęp}

$\mathrm{Na}$ podstawie analizy literatury stwierdzono, że większość projektów robotów humanoidalnych skupia się na projekcie nóg, pomijając ramię. Traktują ręce robota

\footnotetext{
${ }^{1}$ mgr inż., Akademia Techniczno-Humanistyczna w Bielsku-Białej, Wydział Budowy Maszyn i Informatyki, e-mail: artur.zawada88@gmail.com

${ }^{2}$ dr inż., Akademia Techniczno-Humanistyczna w Bielsku-Białej, Wydział Budowy Maszyn i Informatyki: email: jrysinski@ad.ath.bielsko.pl
} 
jako mniej istotą część, która będzie potrzebna dopiero gdy będzie potrzeba przenoszenia elementów. Oczywiście nie jest to błędne podejście jednak, aby zapewnić stabilność poruszającemu się robotowi kroczącemu należy tak manipulować środkiem ciężkości, aby zawsze znajdował się pomiędzy punktami podporowymi. W przypadku humanoidów, które należą do grupy bipedów, czyli robotów dwunożnych przez większość czasu trwania ruchu robot podparty jest jedynie na jednej nodze. Zapewnienie stabilności podczas takiego ruchu jest możliwe wyłącznie przez przemieszczenie środka ciężkości, nad nogę, która aktualnie jest w fazie podporowej. Należy pamiętać, że, od aktualnej pozycji rąk robota zależeć będzie środek ciężkości całej konstrukcji jak. Tak więc, odpowiednio manewrując ramionami można lepiej kontrolować ruch robota. W przypadku, gdy zewnętrzne wymuszenie spowoduje wytrącenie robota $\mathrm{z}$ równowagi to właśnie za pomocą dynamicznego ruchu rąk można sprawić, że konstrukcja powróci do stanu stabilności. Tę sytuację można z łatwością porównać z rzeczywistą sytuacją, gdzie często przed upadkiem ratujemy się wymachując rękoma. Ostatecznie, gdy robot zostanie wytrącony z równowagi to właśnie za pomocą rąk jest możliwe odpowiednie podparcie umożliwiające ponowne powstanie. Dlatego w niniejszym artykule opisane zostały poszczególne etapy wyprowadzania równań kinematyki dla ramion robota humanoidalnego własnego projektu.

\section{Analiza kinematyczna ruchu ręki}

Kinematyka ruchu ręki to pojęcie szeroko stosowane i wielokrotnie już opisywane w publikacjach naukowych np. $[1 \div 8]$. Nie mniej jednak przed przystąpieniem do analizy kinematyki ruchu konieczne jest zaznajomienie się z badanym układem oraz opisanie go za pomocą równań matematycznych, które z kolei są z łatwością interpretowane przez komputerowe systemy obliczeniowe.

\subsection{Analiza kinematyki ruchu ręki człowieka}

W dzisiejszych czasach często spotykamy się $\mathrm{z}$ pojęciem manipulatora. Pierwowzorem tego pojęcia była ludzka ręka, Ryszard Zdanowicz w swojej książce [2] określił manipulator jako maszynę do realizacji niektórych funkcji górnych kończyn człowieka. Jak sama nazwa wskazuje wzorcem ruchowym dla humanoida będzie człowiek, a w przypadku górnych kończyn będą to ludzkie ręce. Z punktu widzenia kinematyki natomiast ważne będzie $\mathrm{w}$ jaki sposób oraz $\mathrm{w}$ jakim zakresie możliwe będzie wykonywanie ruchu. W ten właśnie sposób na rysunku 1 przedstawiony został model kinematyczny ludzkiej ręki. Na jego podstawie można zauważyć kilka ważnych cech. Pierwszą z nich i nie jako najważniejszą z punktu widzenia manewrowości jest liczba osi względem, których możliwy jest do wykonania ruch. Na rysunku wszystkie osie zostały oznaczone literami q. Dla zachowania zgodności ze standardem numerowania oznaczono je kolejno od barku „q1” do nadgarstka ,q7”. Już w tym miejscu możemy zauważyć różnicę pomiędzy standardowym manipulatorem, który jest wyposażony jedynie w sześć osi. Kolejną różnicą jest rozłożenie tych osi. Z punktu widzenia mechaniki bardzo trudne w wykonaniu jest połączenie kinematyczne jak w barku czy nadgarstku ze względu 
na trzy przecinające się w jednym miejscu osie obrotu. Nawet jeżeli udało by się wykonać takie połączenie to problem pojawi się przy algorytmie sterowania.

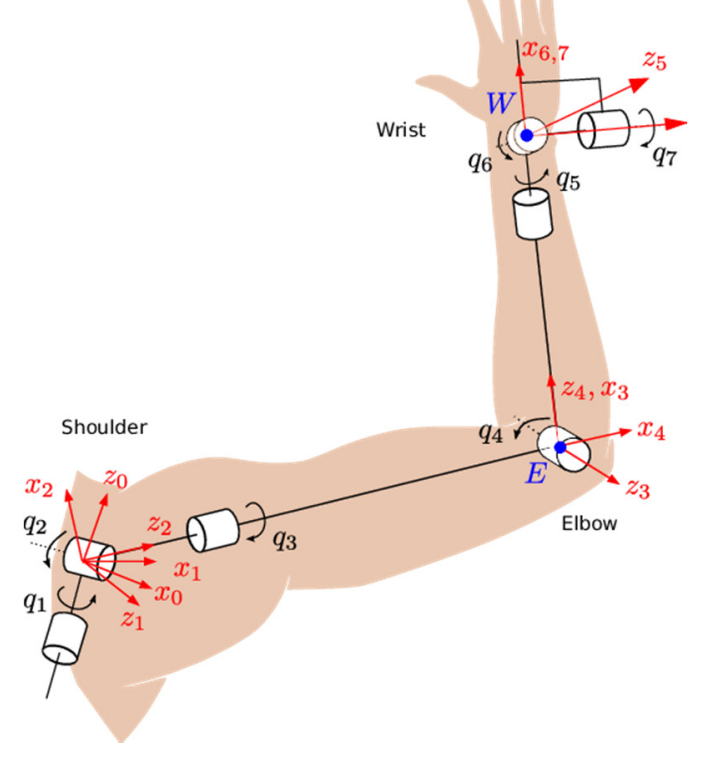

Rysunek 1. Model kinematyczny ludzkiej ręki [12]

W przypadku manipulatorów przemysłowych do wyznaczania równań kinematyki odwrotnej stosuje się metody numeryczne. W przypadku tak złożonego mechanizmu jest to jedyna metoda. Niestety ma ona kilka wad. Pierwszą z nich jest czas obliczeń, który jest znacznie dłuższy niż w przypadku metod analitycznych. Drugą natomiast są pozycje osobliwe (ang. singularity), które posiadają nieskończenie wiele rozwiązań. Układ sterowania nie potrafi określić, które rozwiązanie jest prawidłowe w danej sytuacji. W przypadku manipulatorów sześcioosiowych posiadamy co najmniej kilka takich sytuacji.
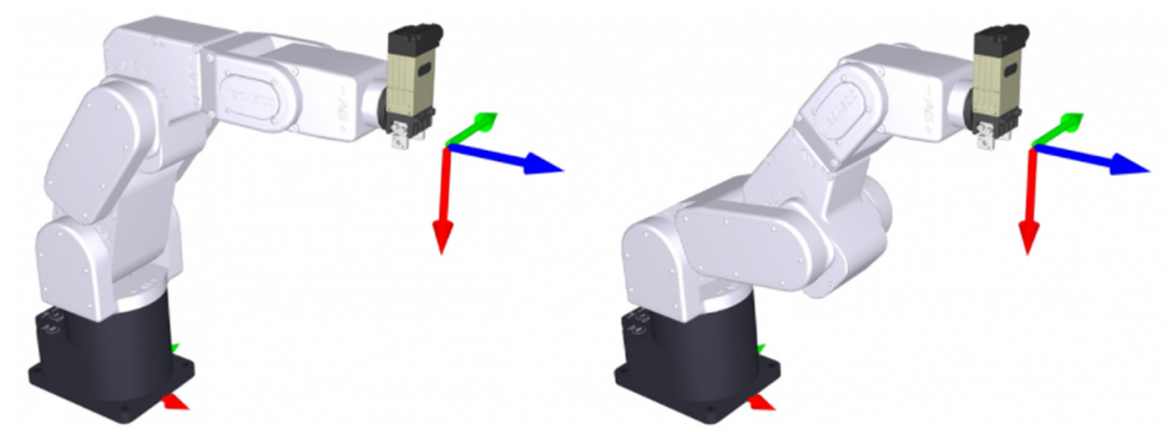

Rysunek 2. Przykład pozycji osobliwej (po lewej) oraz nie osobliwej(po prawej) efektora [13]

Na rysunku 2 przedstawiona została pozycja osobliwa (po lewej) oraz nie osobliwa (po prawej) przy zachowaniu takiej samej pozycji efektora końcowego (TCP ang. 
Tool center point). Możemy zauważyć, że w przypadku osobliwości oś piata została wyzerowana, przez co osie czwarta oraz szósta pokrywają się. Taka pozycja posiada nieskończenie wiele rozwiązań, ponieważ obracając się o dowolny kąt na osi czwartej oraz o taki sam w przeciwną stronę na osi szóstej uzyskamy tę samą pozycje punktu TCP. Metoda numeryczna polega na szukaniu rozwiązań, które przybliżają nas do rozwiązania $\mathrm{z}$ dopuszczalnym bledem. W przypadku gdy rozwiązań jest nieskończenie wiele metoda ta jest bezużyteczna. Analogiczna sytuacja wystąpi w przypadku, gdy osie druga oraz trzecia się wyzerują i wówczas os pierwsza pokryje się z osią czwartą. Odnosząc się z tymi informacjami do rysunku 1 (Rys. 1) można zauważyć, że podobna sytuacja wystąpi w przypadku, gdy kąt ,q4” wyniesie zero stopni powodując pokrycie się osi trzeciej z piątą. W przypadku ludzkiej ręki występuje nadmiarowość manewrowości spowodowana siódmą osią przez co praktycznie każdą pozycje możemy osiągnąc na nieskończenie wiele sposobów. Każda osoba czytająca ten artykuł może samodzielnie udowodnić tę tezę poprzez mały eksperyment, w którym chwyci dłonią dowolny nieruchomy przedmiot. Następnie nie ruszając dłonią spróbujmy wykonać ruch ręką tak aby łokieć znalazł się w innym miejscu. Oczywiście poza kilkoma pozycjami, gdzie występują już ograniczenia na stawach jest to jak najbardziej możliwe. Oznacza to, że zadaną pozycje możemy osiągnąć na nieskończenie wiele sposobów jak w przypadku osobliwości. Z tego powodu projektując ręce robota często ograniczamy liczbę osi, a co za tym idzie liczbę serwomechanizmów odpowiedzialnych za ruch.

\subsection{Analiza kinematyki ruchu ręki robota}

Jak zostało wspomniane wcześniej od ilości zastosowanych napędzanych osi obrotowych zależeć będzie kinematyka manipulatora (ramienia robota). Dokładniej mówiąc jego manewrowość. Upraszcza się natomiast konstrukcja oraz zastosowane obliczenia do wyznaczania kinematyki odwrotnej. W dużej mierze manewrowość zależy od docelowych wymiarów robota ze względu na rozmiary, masę, moment obrotowy oraz rozłożenie serwomechanizmów. Dotyczy to również napędów odpowiedzialnych za ruch nóg, gdyż muszą one utrzymać robota w stanie równowagi mimo wychylenia rąk. Dlatego w niewielkich modelarskich rozwiązaniach ogranicza się ruch rąk do trzech napędów jak na rysunku 3. Dodatkowo w dłoni umieszczony jest niewielki serwomechanizm odpowiedzialny za ruch palców robota.

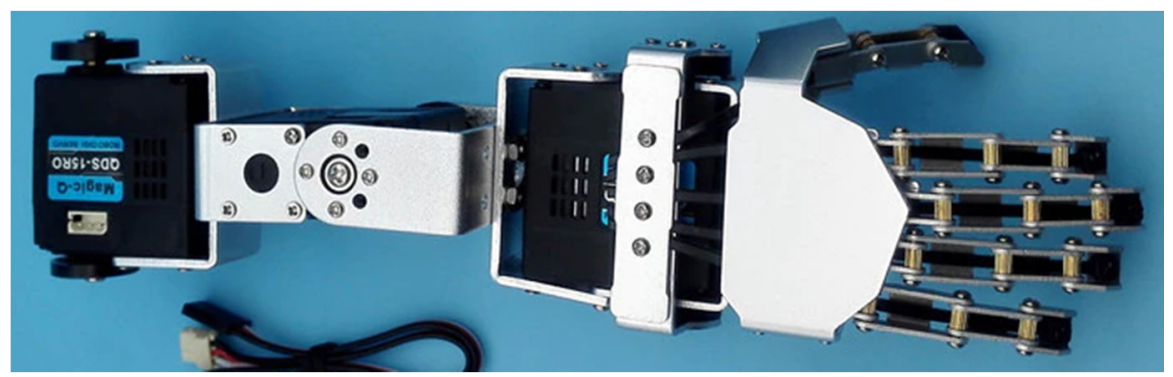

Rysunek 3. Przykładowe ramię robota [14]

Na rysunku 4 przedstawiony został przykładowy robot „Achilles” na podstawie którego wyprowadzone zostaną równania kinematyki odwrotnej. Do jej wyznaczenia konieczna jest znajomość poszczególnych wymiarów oraz odpowiednie oznaczenie 
kątów. Długości L2 oraz L3 zaznaczone na lewej ręce odpowiadają kolejno długością od barku do łokcia oraz od łokcia do nadgarstka. Wymiar L1 stanowi odległości pomiędzy serwomechanizmami umiejscowionymi $w$ barku natomiast L4 w nadgarstku. W przypadku rzeczywistej ludzkiej ręki wartości L1 oraz L4 są równe zero. Odległość „Arm_y_Offset” oznacza odległość od osi y od środka układu robota. Analogiczne do długości na prawej ręce zaznaczone zostały kąty $\Theta$ gdzie $\Theta 1$ oraz $\Theta 2$ odpowiadają za ruch w barku, $\Theta 3$ w łokciu oraz $\Theta 4$ w nadgarstku. Kąt $\Theta 5$ został zaznaczony jedynie poglądowo. Nie wlicza się go do ciągu łańcucha kinematycznego, gdyż jest odpowiedzialny za zamknięcie dłoni nie wpływając na jej położenie końcowe.

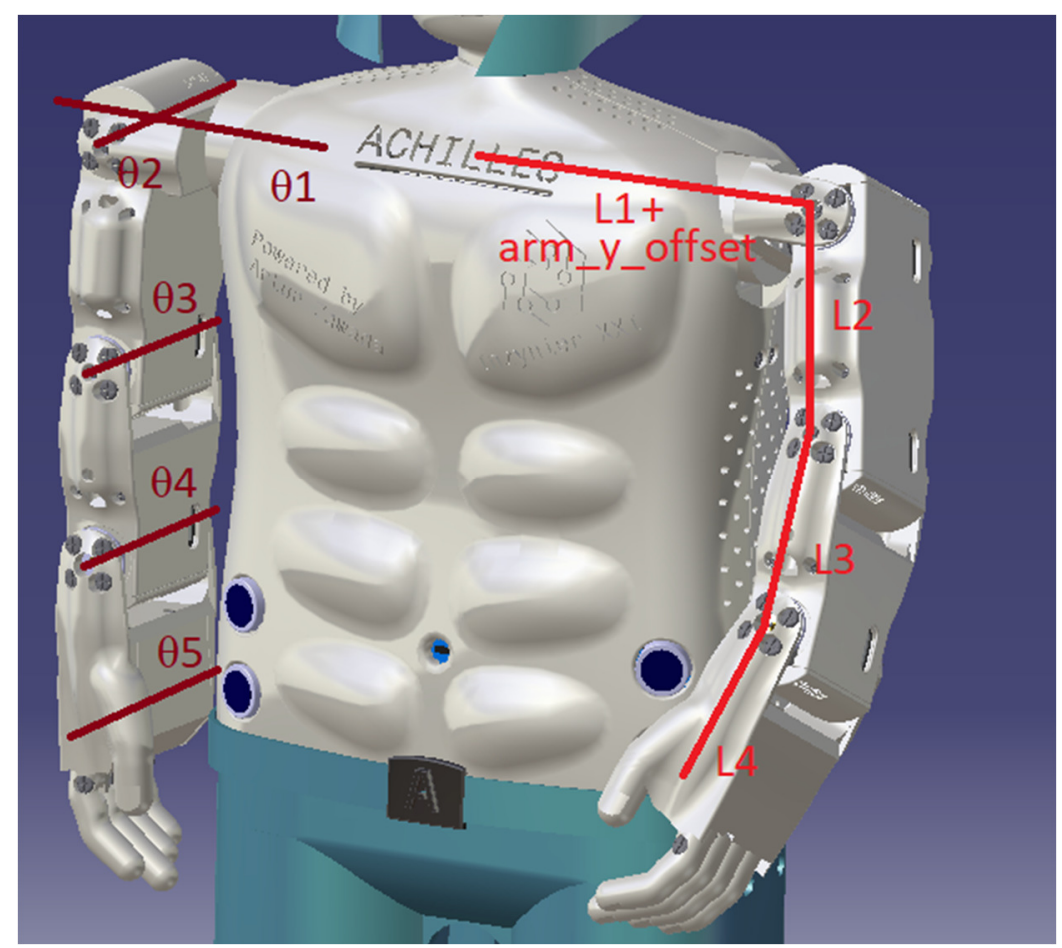

Rysunek 4.Oznaczenie wymiarów robota $(\Theta-k a ̨ t, L$-dtugość) - opracowanie wtasne

\section{Równania kinematyki ruchu}

Posiadając wszystkie konieczne dane można przystąpić do wyprowadzania równań kinematyki. Ze względu na zastosowane uproszczenia, w opisywanym przykładzie zastosowana zostanie metoda geometryczna. Podczas analizy taka metoda jest prostsza i łatwiejsza do przedstawienia zależności, które występują pomiędzy poszczególnymi elementami łańcucha kinematycznego. Na podobnej zasadzie opisana została kinematyka ruchu nóg tego robota własnej konstrukcji [10]. 


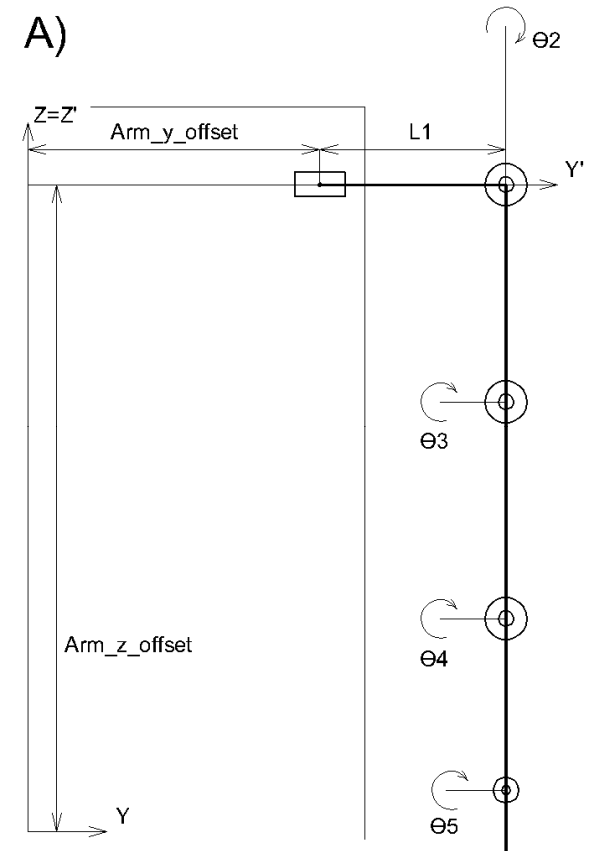

B)

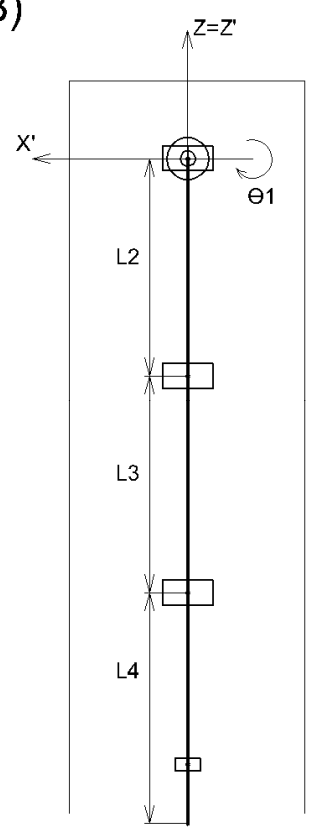

Rysunek 5. Wymiary lewego ramienia

Nim przystąpimy do wyznaczania kinematyki odwrotnej należałoby wyprowadzić tabelę kinematyki prostej. Dzięki temu będzie można na bieżąco odczytywać aktualną pozycję końca ręki oraz posłuży ona do weryfikacji poprawności obliczeń kinematyki odwrotnej. Tabela 1 (Tabele 1) została utworzona zgodnie z założeniami notacji Denavita-Hartenberga dla ręki lewej przedstawionej na rysunku 5.

Table 1. Kinematyka lewej ręki robota

\begin{tabular}{ccccc}
\hline l.p. & $\begin{array}{c}\text { Rotacja } \\
(\theta)\end{array}$ & TranslacjaZ $(d)$ & $\begin{array}{c}\text { TranslacjaX } \\
(a)\end{array}$ & Rotacja X $(\alpha)$ \\
\hline 1. & 0 & Arm_z_offset & 0 & -90 \\
2. & $\Theta 1$ & L1+Arm_y_offset & 0 & 0 \\
3. & 90 & 0 & 0 & 90 \\
4. & $\Theta 2$ & 0 & L2 & 0 \\
5. & $\Theta 3$ & 0 & L3 & 0 \\
6. & $\Theta 4$ & 0 & L4 & 0 \\
\hline
\end{tabular}

Na podstawie tego samego rysunku można zauważyć, że wszystkie kąty $\Theta$ będą ze sobą ściśle powiązane jednak jedynie kąt $\Theta 1$ umożliwia przemieszczanie dłoni w płaszczyźnie OXZ. W sytuacji, gdy będzie on równy zero jakakolwiek zmiana kątów @2-4 nie spowoduje zmiany położenia w tej płaszczyźnie (wychylenia ręki przód-tył). 
A)

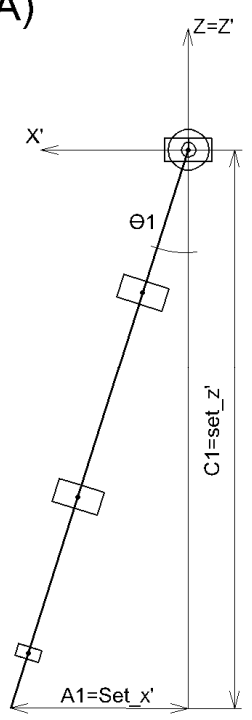

B)

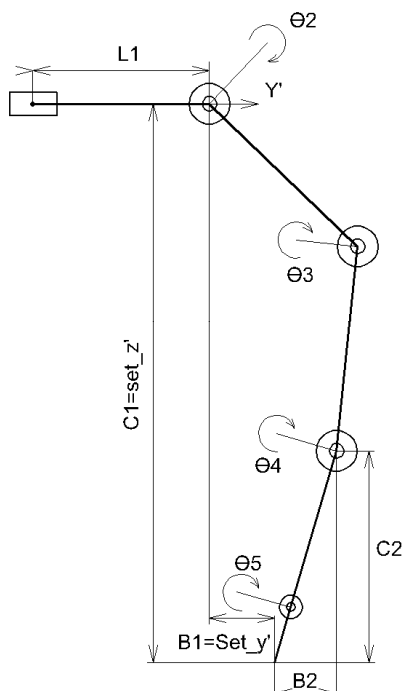

C)

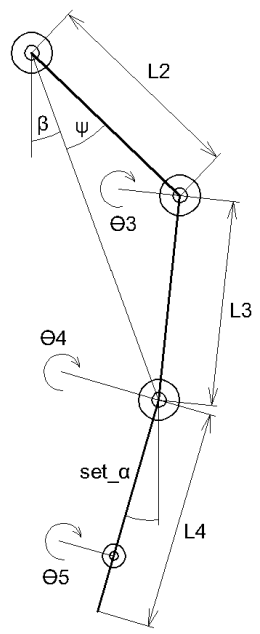

Rysunek 6. Pozycja lewej dtoni względem barku

W tabeli 1 można zauważyć dwa parametry arm_y_offset oraz arm_z_offset mają one na celu przeniesienie początku układu współrzędnych $\mathrm{z}$ globalnego układu współrzędnych robota do początku ramienia, czyli do barku. Na rysunku 6 zaznaczono natomiast parametry set_x', set_y' oraz set_z' które wskazują na zadaną pozycje dłoni robota względem barku. Pozycje te uwzględniają offset początku ramienia i można je przeliczyć korzystając z zależności (1):

$$
\operatorname{set}_{x}=\operatorname{set}_{x}^{\prime} \mid \operatorname{set}_{y}=\operatorname{set}_{y}^{\prime}+\operatorname{arm}_{y} \text { offset | } \operatorname{set}_{z}=\operatorname{set}_{z}^{\prime}+\operatorname{arm}_{z} \text { offset }
$$

Do wyznaczenia wartości kąta $\Theta 1$ (3) można by wykorzystać funkcje arcustangens jednak funkcja ta dąży do nieskończoności przy wartości, $90^{\circ}$ dlatego należy zastosować funkcje arcuscosinus. Mimo iż to rozwiązanie jest bezpieczniejsze należy uwzględnić w nim moment, gdy funkcja zmienia znak. $Z$ tego powodu w argumencie funkcji znalazła się wartość bezwzględna natomiast całość została przemnożona przez $A 1 /|A 1|$. Taki zabieg ma na celu uzyskanie dodatniej wartości kąta $\Theta 1$ przy set_x’ $>0$ oraz ujemnej przy set_x' $<0$. Obliczony w równaniu (2) parametr $C$ będący argumentem funkcji arcustangens informuje nas jaka musi być docelowa długość ramienia. W tym miejscu należy zastosować przerwanie dalszych obliczeń, jeżeli wartość $\mathrm{C}$ jest większa niż maksymalna długość ramienia.

$$
\begin{gathered}
\mathrm{C}=\sqrt{A 1^{2}+C 1^{2}}=\sqrt{\left(\operatorname{Set}_{x}\right)^{2}+\left(\operatorname{Set}_{Z}\right)^{2}} \\
\Theta 1=\arccos \left(\frac{|A 1|}{C}\right) * \frac{A 1}{|A 1|} * \frac{180}{\pi} \quad A 1 \neq 0
\end{gathered}
$$


Na podstawie rysunku 6 można zauważyć, że zadana pozycja dotyczy dłoni robota, która jest końcem łańcucha kinematycznego. Długość L4 określa odległość od dłoni do serwomechanizmu odpowiedzialnego za ruch nadgarstka. Zadana wartość set_ $\alpha$ definiuje natomiast kąt pod jakim należy ustawić dłoń do płaszczyzny Oxz. Biorąc pod uwagę te zależności można zauważyć, że jedynie set_ $\alpha$ wpływa na rzut długości L4 na płaszczyzny Oxz oraz Oyz. Rzuty te zostały kolejno oznaczone C2 oraz B2 na rysunku $6 \mathrm{~B}$. W ten sposób możemy uzyskać kolejne dwa równania (4)(5) oraz pominąć ostatni element łańcucha kinematycznego. Ograniczając się jedynie do wyznaczenia pozycji nadgarstka, należy wziąć pod uwagę znak przy kącie $\alpha$ (5) wprowadzając dodatkowy warunek.

$$
\begin{gathered}
C 3=C 1-C 2 \\
B 3=B 1+B 2 \text { dla } \propto>0 \quad \mid B 3=B 1-B 2 \text { dla } \propto \leq 0
\end{gathered}
$$

Kolejnym krokiem jest wyznaczenie wartości $\Theta 2$ (8), który jest sumą kątów $\psi$ oraz $\beta$ do których obliczenia wykorzystane zostały zależności geometryczne (6) oraz (7).

$$
\begin{gathered}
\beta=\arctan 2\left(B_{3}, C_{3}\right) \\
\psi=\arccos \left(\frac{C_{3}{ }^{2}+B_{3}{ }^{2}+L 2^{2}-L 3^{2}}{2 * L 2 * \sqrt{C_{3}{ }^{2}+B_{3}{ }^{2}}}\right) \\
\theta 2=(\beta+\psi) * \frac{180}{\pi}
\end{gathered}
$$

Analogiczna zależność (9) wykorzystana została do uzyskania kąta $\Theta 3$. W przypadku manipulatorów możliwe jest przeginanie łokcia w obu kierunkach $\left(-90^{\circ}, 90^{\circ}\right)$ jednak w przypadku ramienia robota humanoidalnego wprowadzone zostanie ograniczenie zgodne $\mathrm{z}$ ograniczeniami ludzkiego stawu łokciowego. Kąt ten zawsze będzie mniejszy lub równy 0 stąd w równaniu (9) pojawił się minus.

$$
\Theta 3=\arccos \left(\frac{C_{3}{ }^{2}+B_{3}{ }^{2}-L 2^{2}-L 3^{2}}{2 * L 2 * L 3}\right) *-\frac{180}{\pi}
$$

Pozostała nam ostatnia zależność (10) mająca wpływ na wartość kąta Ө4. Jak wcześniej zauważyliśmy kąt set_ $\alpha$ będzie definiował równoległość dłoni w stosunku do płaszczyzny Oxz. Nie jest to jednak docelowa wartość kąta $\Theta 4$, ponieważ konieczne jest uwzględnienie odchylenia spowodowanego kątami $\Theta 2$ oraz $\Theta 3$. Na tej podstawie można wyznaczyć ostatnią zależność.

$$
\theta 4=-(\theta 2+\theta 3)+\propto
$$

Zależności 1-10 są prawdziwe dla ręki lewej opartej na czterech serwomechanizmach. Aby wykorzystać je dla prawej ręki konieczna będzie zmiana znaków na przeciwne. Równania te również będą prawdziwe, jeżeli dołożymy kolejną oś do nadgarstka umożliwiającą jego obrót wokół własnej osi. Wartość tego obrotu nie będzie miała 
wpływu na pozycję końcową dłoni a jedynie na jej orientację. Inaczej sytuacja będzie wyglądać, gdy dołożymy kolejną oś w barku co znacznie utrudni obliczenia. Aby zweryfikować poprawność obliczeń należy zadać pozycję docelową, a następnie za pomocą kinematyki prostej sprawdzić czy uzyskane kąty pozwolą na osiągnięcie zadanej pozycji.

$$
\begin{aligned}
\operatorname{Max}_{\text {diff }} & =\operatorname{Max}\left(\operatorname{Max}_{\text {diff }},\left|\operatorname{Last}_{i}-\operatorname{Act}_{i}\right|\right) \quad i \in 1 \ldots 5 \\
\operatorname{Velocity}_{i} & =\operatorname{map}\left(\left|\operatorname{Last}_{i}-\operatorname{Act}_{i}\right|, 0, \text { Max }_{\text {diff }}, 0, \text { Set }_{\text {velocity }}\right)
\end{aligned}
$$

Aby płynnie sterować ruchem rąk pozostaje jeszcze wyznaczyć prędkości i przyśpieszenia. W przypadku prędkości należy znaleźć największą różnicę pozycji spośród wszystkich serwomechanizmów, a następnie na zasadzie proporcji przypisać poszczególne prędkości. Aby to zrobić można skorzystać z zależności (11) oraz (12). Funkcja max w zależności (11) ma na celu znalezienie maksymalnej różnicy pozycji, gdzie Last $\Theta_{i}$ oznacza ostatnią znaną pozycję natomiast Act $\Theta_{i}$ zadaną. Widoczna W równaniu (12) funkcja map pozwala na proporcjonalne skalowanie w zakresie od 0 do $100 \%$ zadanej prędkości dla różnicy pozycji od 0 do maksymalnej. Wyznaczenie przyśpieszenia natomiast zależne będzie od gabarytów ręki oraz możliwości serwomechanizmów. Nie jest możliwe wyznaczenie uniwersalnego równania opisującego tę zależność. Ostatnim z elementów ręki robota jest efektor. Budowa ludzkiej dłoni jest znacznie bardziej skomplikowana niż sama ręka. Na ruch samego kciuka potrzebowalibyśmy trzy serwomechanizmy, przez co w niewielkich konstrukcjach nie jest możliwe pomieszczenie wszystkich napędów. Z tego powodu często ograniczamy się jedynie do jednego serwomechanizmu pozwalającemu na jednoczesny ruch wszystkich palców. Wartość kąta $\Theta 5$ będzie wynosiła od 0 dla pełnego otwarcia do $100 \%$ dla pozycji zamknięcia. Dokładne wartości wynikać będą $\mathrm{z}$ budowy cięgien i umiejscowienia napędu.

\section{Wnioski}

W niniejszym artykule podjęto próbę opisu zależności kinematyki ruchu ręki robota. Przedstawiono metody oraz sposoby rozwiązania problemu. Dzięki zastosowanym uproszczeniom możliwe było zastosowanie metody geometrycznej do wyznaczania parametrów konstrukcji. Metoda ta jest bardzo prosta i umożliwia lepsze zrozumienie tak skomplikowanego zagadnienia. Do precyzyjnego wyznaczenia pozycji dłoni robota wystarczające było zastosowanie dziesięciu równań, uzupełnionych o dwa, związane z prędkością ruchu. Dla prezentowanego układu metody numeryczne są bardziej skomplikowane i konieczne jest duże zapotrzebowanie mocy obliczeniowej urządzenia. Otrzymane wyniki zależne są od zadanej dokładności, co ma wpływ na czas obliczeń. Niestety skuteczność metody geometrycznej ogranicza się do prostych układów, przez co nie umożliwia pełnego odwzorowania ruchu ludzkiej ręki. Jej zaletą natomiast jest prosta implementacja oraz możliwość zastosowania przez osoby nieposiadające wiedzy na temat obliczeń numerycznych. 
Jak można zauważyć, metoda geometryczna przy wprowadzeniu kilku założeń upraszczających pozwala na kompleksowe sterowanie nie tylko ruchem poszczególnych kończyn, ale także ruchem całego robota humanoidalnego.

\section{LITERATURA}

1. CRAIG J.: Introduction to robotics: Mechanic and control, Third edition, Pearson Education International inc. 2005.

2. ZDANOWICZ R.: Podstawy robotyki, Politechnika Śląska 2012.

3. MOESLUND T.B., GRANUM E.: Modelling and estimating the pose of a human arm, Machine Vision and Applications 14(2003)4, 237-247, DOI:10.1007/s00138-002-0090-1.

4. SEUNGSU KIM, CHANGHWAN KIM, JONG HYEON PARK: Human-like Arm Motion Generation for Humanoid Robots Using Motion Capture Database, IEEE Xplore 2006, DOI:10.1109/IROS.2006.282591.

5. SCIAVICCO L., SICILIANO B.: Modelling and Control of Robot Manipulators, Measurement Science and Technology 11(200)12,1828, DOI:10.1088/09570233/11/12/709.

6. LENARCIC J., THOMAS F.: Advances in Robot Kinematics: Theory and Applications, 2002, DOI:10.1007/978-94-017-0657-5,

ISBN: 978-90-481-6054-9.

7. ZATSIORSKY V.: Kinematics of human motion. Human Kinetics, Human Kinetics 1998, ISBN-13: 978-0880116763.

8. GAMS A., LENARCIC J.: Humanoid arm kinematic modeling and trajectory generation, IEEE In-ternational Conference on Biomedical Robotics and Biomechatronics, BioRob, 2006, 10.1109/BIOROB.2006.1639103.

9. ZAWADA A., JANUSZ J.: Design and implementation arm controlled by microprocessor, Akademia Techniczno-Humanistyczna w Bielsku-Białej 2019

10.ZAWADA A., RYSIŃSKI J.: The first steps of a humanoid robot, Akademia Techniczno-Humanistyczna w Bielsku-Białej 2020.

11.ZAWADA A.: Projekt oraz wykonanie robota dwunożnego, Praca dyplomowa, Akademia Techniczno-Humanistyczna w Bielsku-Białej 2020.

12.ZANCHETTIN A.M., ROCCO P., BASCETTA L., SYMEONIDIS I., PELDSCHUS S.: Kinematic motion analysis of the human arm during a manipulation task, Conference: Robotics (ISR), 2010 41st International Symposium on and 2010 6th German Conference on Robotics (ROBOTIK), 12521257.

13. Serwis internetowy: Mecademic https://www.mecademic.com/en/what-aresingularities-in-a-six-axis-robot-arm, 28.10.2021

14. Serwis internetowy: https://pl.aliexpress.com/item/32771102406.html, 28.10.2021. 